\title{
POLYBIUS AND LIVY ON THE ALLIES IN THE ROMAN ARMY
}

\author{
PaUl ERdKamp*
}

From the fourth or third century until the beginning of the first century BC, Rome's armies were also the armies of her allies. The socii and nomen Latinum raised at least half of the soldiers that fought wars for Rome. The Italic allies were clearly distinguished from the non-Italic troops, such as Cretan archers or Numidian horsemen, by the fact that they were governed by the formula togatorum. This can be concluded from their 'definition' in the lex agraria from 111 BG: socii nominisve Latini quibus ex formula togatorum milites in terra Italia imperare solent. The formula togatorum is seen as a defining element, distinguishing the Latin and Italic peoples from Rome's overseas allies. Although in the second century BG a consciousness of Italy as a political and cultural unity gradually emerged, it was still referred to as a military alliance of Roman citizens and allies at the end of that century. ${ }^{1}$ The beginnings of this system remain in the dark, due to the inadequacies of our sources. The foedus Cassianum between Rome and the Latin League (traditionally dated to $493 \mathrm{BC}$ ) supposedly established a federal army under Roman command, but next to nothing is known about its functioning. The participation of the allied peoples was based on the treaties between their communities and Rome. The position of the Latin colonies was slightly different, because their obligations were probably based on the lex coloniae governing each Latin colony. ${ }^{2}$ We may assume that the role of the allies was re-defined

* I wish to thank John Rich, Luuk de Ligt and Simon Northwood for their many valuable comments.

1 Thus, T. Hantos, Das römische Bundesgenossensystem in Italien (München 1983), 185; P.A. Brunt, 'Italian aims at the time of the Social War,' in The fall of the Roman republic and related essays (Oxford 1988), 113. On the term socii Italici, E. Gabba, 'Rome and Italy in the second century BG', Cambridge Ancient History VIII (Cambridge 1989), 209 observes, "it is only in relation to the predominant partner, that is to say Rome, that they are seen as a group and thus bear this title".

2 W.V. Harris, Rome in Etruria and Umbria (Oxford 1971), 85ff.; H. Galsterer, Herrschaft und Verwaltung im republikanischen Italien. Die Beziehungen Roms zu den italischen Gemeinden vom Latinerfrieden 338 v.Chr. bis zum Bundesgenossenkrieg 91 v.Chr. (München 1976), 84ff., 101ff;; Hantos 1983, op. cit. (n. 1), 150ff; D.W. Baronowksi, 'Roman treaties with communities 
after the Latin War, but we know little about this or how the system worked and developed during the next century.

In the absence of documentary evidence, we have to rely largely on the literary sources. Dionysius of Halicarnassus (20.1.5) may offer a rare glimpse of the structure of the Roman army at an early date, when he tells us that at the battle of Ausculum against Pyrrhus (279 BC), Latins, Campanians, Sabines, Umbrians, Volsci and Frentani were divided into units that were posted between the legions. This is the more remarkable, as the Campanians were cives sine suffragio, who at least at the end of the century served in the legions. However, there is no evidence that corroborates Dionysius, and so it remains likely that we are dealing with "eine reine Phantasieschilderung". ${ }^{3}$ Livy is missing until the Hannibalic War, while Polybius' narrative of Roman wars in books 1 and 2 is nearly silent on the role of the allies, except for the famous survey of peoples joining Rome against the Gauls in 225 BG. His account of the Gallic threat leading to mass mobilisation of citizens and allies in $225 \mathrm{BC}$ sheds sudden light, mentioning the formula togatorum and manpower figures, but the passage is notoriously fraught with problems.

When the sources start to offer information on the allies, all seems well-established. Livy gives us no general account of the Roman army, comparable to book six in Polybius' Histories, since he is not interested in analysing the Roman state and its institutions. However, his narrative of Roman war in books 21-45 seems to give a good view of the allied system as it functioned during the half-century from 218 to $167 \mathrm{BG}$. In these books, Livy mentions units consisting of allied peoples (the Paeligni, Marrucini, Vestini and Marsi) and Latin colonies (Firmum, Fregellae, Aesernia, Cremona and Placentia). Moreover, we also meet cohorts from Gaul and Picenum, ${ }^{4}$ and cavalry units of Latin, Lucanian and Etruscan horsemen. In 213 Bc, for example, Vibius Accaus from Paeligna, praefectus of a cohors Paeligna, is rewarded for bravery during a battle near Beneventum against Hanno (Livy 25.14.13). In 204, four cohortes sociorum Latini nominis are stationed as garrsion in Locri in Bruttium (29.19.9). Twice Livy mentions a praefectus socii operating inde-

of citizens,' Classical Quarterly 38 (1988), 172-178; id., 'Sub umbra foederis aequi', Phoenix 44 (1990), 345-369; D. Timpe, 'Erwägungen zur jüngeren Annalistik', Antike und Abendland 25 (1979), 379ff.

${ }^{3}$ Galsterer 1976, op. cit. (n. 2), 106.

${ }^{4}$ Mobilised during an emergency levy. Livy 23.14.2. 
pendently against the enemy, losing the battle and his life. ${ }^{5}$ At Pydna, Marrucinian, Paelignian and Vestinian cohorts fought side-by-side with Samnite or Latin turmae (44.40.4ff.).

\section{Polybius}

In contrast, Polybius hardly ever mentions the allies explicitly in his account of Roman wars between 218 and 168 BC, although his theoretical passages on the Roman army in book six and elsewhere paint a clear picture of how they functioned. It is sometimes argued by modern scholars that, in contrast to Livy, Polybius underestimated the role of the allies. ${ }^{6}$ See, for instance, the following statement by E. Gabba: "Convinced as he was of the solidity of the Roman state, he saw no need to analyse the bases of the political organization of Roman Italy or indeed the relations between Rome and her allies. Proof lies in his description of Roman military organization in terms of a single citizen militia. In this context, the allied contingents are depicted as integrated and homogeneous parts of the Roman army."

A typical example of a Polybian battle account is that of the battle of Zama, in which the Romans under the command of Scipio Africanus defeated Hannibal's army in 202 Ba. Such an important battle receives full treatment by Polybius, including a survey of the Roman and Carthaginian battle array:

Scipio drew up his army in the following fashion. In front he placed the hastati with certain intervals between the semaiai and then the principes, not placing their speirai, as is the usual Roman custom, opposite to the intervals separating those of the first line, but directly behind these latter at a certain distance owing to the large number of the enemy's elephants. Last of all he placed the triarii. On his left wing he posted Gaius Laelius with the Italian horse, and the right wing Masinissa with the whole of his Numidians. The intervals of the first semaiai he filled up with the speirai of the velites, ordering them to open the action, and if they were forced back by the charge of the elephants to retire, those who had time to do so by the straight passages as far as the rear of the whole army, and

${ }^{5}$ Livy 25.1.3f.; 31.2.5ff.

${ }^{6}$ Rejected by W.V. Harris, 'The Italians and the empire', in W.V. Harris, ed., The imperialism of mid-republican Rome (Rome 1984), $89 \mathrm{ff}$.

${ }_{7}$ Gabba 1989, op. cit. (n. 1), 210. 
those who were overtaken to right or left along the intervals between the lines. (Polybius 15.9.6-10)

Attention to the contribution of Rome's Italian allies is limited to the cavalry: the Italian cavalry is posted on the left wing. The posting of the Numidian horse on the right wing, however, and the absence of any Roman cavalry makes clear that the Italian cavalry in this case in fact includes that of Roman citizens. Typically Polybius, one might say: 'Roman' or 'Italian' is almost synonymous. This is also indicated by his use of such a phrase as "the allied horse of the Romans" in his account of the battle of Cannae (3.116.6). In his account of the battle of Zama, the Roman army in general or parts of it are referred to in such general terms as 'the Romans' or 'the infantry', and in technical terms, such as hastati, principes and triarii. However, not once do we see an explicit reference to the allied infantry.

The picture is the same in all Polybian battle accounts. Apart from the non-Italic allies of Rome, such as the Aetolians or Spanish peoples, the only part of the allied contribution that is ever referred to is the Italian horse (sometimes in the sense of the Roman and allied Italian horse), and that not even in every battle. Concerning the infantry, Polybius mainly uses technical terms for units or differently armed types of soldiers that do not distinguish between Romans or allies. The only 'ethnic' term he often uses is 'the Romans', but this obviously in most cases means all those on the Roman side. In short, in his narrative of military actions, Polybius seems to ignore the distinction between Romans and allies as far as the infantry is concerned.

One obvious way to distinguish Romans from allies, it might be argued, is by the usage of the term 'legion', since legions are manned by Roman citizens. However, the term used by Polybius to indicate a legion - stratopedon - has also much wider meanings. ${ }^{8}$ This is shown for instance in 10.16.4, in which Polybius has the general observation that a consular army consists of "two Roman stratopeda and two of the allies". Clearly, also the allies were organized in what Polybius calls a stratopedon. The term can have at least three meanings in the histories of Polybius: 1. that of 'army' in general; 2. that of a large unit of heavy infantry in Roman or other armies and 3. as the equivalent of 'legion'. The Loeb translation by W.R. Paton tends to translate the term as 'legion,' but

${ }^{8}$ Cf. M. Gelzer, 'Die Glaubwürdigkeit der bei Livius überlieferten Senatsbeschlüsse über römische Truppenaufgebote', Hermes 70 (1935), 283. 
that is misleading, since many times the term clearly refers to citizen as well as allied troops. ${ }^{9}$

The same applies to Polybius' terminology for the sub-units of the stratopedon. The main term he uses is 'semaia', which is derived from the word for the standard of a unit; the direct Latin equivalent is signum, not only meaning standard, but also unit (cf. vexillum). Basically, the semaiai are the tactical units grouped around a military standard. Polybius mainly uses the term semaia as the Greek equivalent of manipulus. This is most clearly shown in 6.24, where Polybius describes the structure of the Roman legion. In battle, he writes, the three main lines are: the hastati, the principes and the triarii. Each of these is divided in 10 companies, the maniples. "These companies are known as tagma, speira or semaia." 10 The rest of the passage clearly shows that the three terms are used as equivalent in meaning. It is only for the sake of variation that Polybius sometimes uses semaia and speira in the same passage for the same thing. (See for instance the first lines of the battle array at Zama quoted above.) In short, the main term for manipulus, which is the primary tactical unit of the Roman legions in Polybian times, is semaia, less often speira. Now, the point is that these terms might also refer to allied troops. This is for instance clearly shown in 6.30.4, where Polybius mentions the semaiai of the allied infantry. A wider meaning of the term is also indicated in 15.4.4, where it is used as "ten units of Roman horse and foot". In Latin, one cannot use manipulus as referring to horse. In sum, even such a basic term, which is used as the Greek equivalent of the Latin manipulus, and which occurs numerous times in Polybius' narrative of military operations, refers to allies as well as Romans.

One last item may be allowed to confirm this point: Polybius informs us in book six that a Roman legion had six military tribunes (chiliarchoi), its main officers. The allied equivalent of the military tribune, he writes, is the prefect of the allies, in Latin the praefectus sociorum. ${ }^{11}$ It may be noted that the prefects of the allies were Roman citizens, just as the military tribunes were. Hence, there is little difference between them in this regard. The interesting part is that Polybius very often - in almost

\footnotetext{
9 Polybius, The histories, transl. W.R. Paton (Cambridge MA 1922).

10 Polybius 6.24.5.

11 Polybius 6.26.5; 6.37.8.
} 
every battle narrative - mentions military tribunes doing this or that. ${ }^{12}$ In contrast, he never ever mentions prefects of the allies. Should we assume that the term chiliarchos is used to refer to both? Although it is difficult to prove, it does seem likely.

Hence, when in his battle descriptions, such as that of Zama, Polybius mentions the Romans, the legions, or the maniples, he does not distinguish between citizen and allied troops. However, if Polybius paid any attention to what he wrote himself in book six, he must have been aware of the distinction. Although book six is concerned primarily with the Roman constitution and the citizen troops, he does regularly refer to the allied contingents. Twice he mentions in book six that the allies contributed an equal number of infantry as the Romans. The number of allied horse was three times as high as that of the Romans. ${ }^{13}$ As we have seen, in the consular army, the allies formed two stratopeda along the two stratopeda (or legions) of the Romans. In battle, one allied stratopedon was stationed on the right wing, the other on the left. Part of the allied infantry and cavalry formed a particular group, in Greek the epilektoi, in Latin the extraordinarii. ${ }^{14}$ We also know the position of the allied horse and the allied foot in the consular camp. ${ }^{15}$ There are details, furthermore, concerning recruitment, rations and pay, and rewards for valour. ${ }^{16}$ Hence, it is not correct to say that Polybius ignores the allies. In matter of fact, without Polybius, we would know much less about the allies in the Roman army.

However, what about his silence regarding the allies in his account of military operations? Doesn't that imply a lack of interest and thus show that Polybius underestimated the role of the allied troops? I think not.

\footnotetext{
${ }^{12}$ Some scholars have pointed out that Polybius' account of the Roman army in book six "is written entirely from the point of view of a set of important but subordinate officers, the military tribunes". E. Rawson, "The literary sources for the pre-Marian army', Papers of the British School at Rome 39 (1971), 13-31. Reprinted in Roman culture and society. Collected papers (Oxford 1991), 36 (with older literature). They therefore conclude that Polybius used some kind of instruction to military tribunes as a starting point. The existence of such documents is unproven. Moreover, reliance on written instructions would seem unlikely in an era in which young nobles had seen many campaigns before their term as officers and in which many posts of military tribunes were taken by ex-praetors and ex-consuls. Finally, military tribunes are not only prominent in book six, they also play a large role in Polybius' account of campaigns.

${ }_{13}$ Polybius 6.26.7; 6.30.2. According to P.A. Brunt, Italian manpower (Oxford 1971), 678 , the ratio varied, pointing to Appian and Livy.

${ }^{14}$ Polybius 6.26.7-9.

${ }_{15}$ Polybius 6.31.2-6.32.6.

${ }^{16}$ Polybius 6.39.
} 
The answer is that Polybius described the allied troops as functioning not differently from the Roman troops. As he depicts them, the units of allies and Romans together formed one uniform army, operating in the same way and organised along identical lines. The theoretical passages in Book six and elsewhere support this hypothesis.

The first example is the passage in which Polybius explains the usual procedure in the Roman army for plundering a city and dividing the booty among the soldiers. Polybius emphasizes that many a Greek army had come into trouble when the eagerness of individual soldiers to take spoils resulted in anarchy. In contrast, the Romans went about it in a very disciplined and organised manner. His explanation is given on the occasion of the capture of Carthago Nova in 210 BG.

After a city has been captured the Romans adopt the following procedure with the spoils. According to the size of the town sometimes a certain number of men from each semaia, at other times certain whole semaiai are told off to collect booty. They never use more than half the army on this task, and the rest remain in their ranks, at times outside and at times inside the city, ready for the occasion. The army are usually composed of two Roman stratopeda and two of the allies, and it is only on rare occasions that all four stratopeda are assembled together. All those who have been detailed to collect the plunder then bring it back, each man to his own stratopedon, and after it has been sold, the chiliarchs distribute the proceeds equally among all, including not only those who have been left behind in the protecting force, but also those who are guarding the tents or tending the sick, or who are absent on any special duties. (Polybius 10.16-17) ) $^{17}$

Two elements show that this procedure pertained to the entire army, Romans and allies alike. First is his mention that consular armies consisted of four stratopeda, two of Romans and two of allies. Therefore, the division of spoils among the stratopeda included the allied ones. Secondly, Polybius emphasizes that the system was used to give absolutely all men an equal share in the spoils. In short, the procedure for the division of spoils implies Roman and allied units organized and functioning equally.

The second example is provided by Polybius' account of the Roman marching order. He writes that:

17 On this passage, see A.M. Eckstein, 'Physis and nomos. Polybius, the Romans, and Cato the Elder', in P. Cartledge et al., eds., Hellenistic constructs. Essays in culture, history and historiography (Berkeley 1997), 85. 
At the third signal, the leading troops must advance and set the whole camp in motion. As a rule the extraordinarii are placed at the head of the column; after them come the right wing of the allies and behind them their pack animals. Next in the order is the first of the Roman legions with its baggage behind it, after which comes the second followed by its pack animals, together with the baggage train of the allies, who bring up the rear, the left wing of the allies providing the rearguard. (6.40.3-5)

A different marching order is used when the army expects to meet the enemy:

In this case the army advances in three parallel columns, consisting of the hastati, principes and triarii. The baggage trains of the leading semaiai are placed in front, those of the second immediately behind, and so on, the baggage trains being interspersed between the bodies of fighting troops. With this information, if the column should be threatened, the troops face to the right or left, according to the direction from which the attack comes, and can then quickly get clear of the baggage and confront the enemy. $(6.40 .11)$

While the first passage explicitly distinguishes between the units of allies and Romans, the battle formation of the second passage implies a homogenously organized army consisting of three columns. It is clear that the allies were part of the columns of hastati, principes and triarii.

In his description of the formation of the consular army, Polybius tells us explicitly that the allies are organized by Roman officers. The magistrates of the allied communities were first instructed to send a certain number of troops. Polybius (6.21.5) adds that the magistrates of the allies used the same procedure as the Romans to choose their recruits, each community appointing a commander and a paymaster. At the final stage, the recruits selected from among the citizens and those from the Latin and other allies came together and were divided into units. About this final stage, Polybius writes:

The allies having now assembled also at the same places as the Romans, their organization and command are undertaken by the officers appointed by the consuls known as praefecti sociorum and twelve in number. (Polybius $6.26 .5)$

Moreover, the fittest horsemen and foot soldiers among the allied troops were selected by the Romans in order to form the extraordinarii (6.26.6). Ethnic units of varying size would not fit the army as he describes it, not only in book six, but also in his account of the Roman army on campaign. There is no contradiction between book six and his accounts of Roman campaigns, which at the least does not support the wide- 
spread supposition that book six describes the Roman army as it had once functioned, but not anymore in Polybius' time. ${ }^{18}$

One more important point should be made. The Roman light armed soldiers (velites) were men of little property. The three lines of hastati, principes and triarii represented different age classes. The hastati were the youngest recruits, the principes men in their prime, the triarii were seasoned veterans. ${ }^{19}$ If the allied units were organised in a similar manner, their troops had to be distinguished along similar lines. In other words, also allied troops had to be distinguished according to age and property. This is confirmed by the brief remark that we have seen above concerning the mobilisation of allied troops: the allied magistrates used the same procedure to select their recruits.

We may conclude that Polybius did not ignore or underestimate the role of the allies, on the contrary. However, he chose to depict them as an integral part of the Roman army. It is clear now why he invariably refers to the Roman side as the Romaioi and why he uses general terms like the semaiai, or hastati, principes and triarii to refer to parts of the Roman army. Since the allied units fought in exactly the same way as the Roman maniples, there was little point in distinguishing between them. The Roman armies that Polybius witnessed and described fought as a single body, in which distinctions between citizens and allies were simply not important.

\section{Allies in Livy's battle descriptions}

A similar picture to that in Polybius is found in many of Livy's battle narratives. On occasion we find mention of allies in general terms, usually referring to the allied cavalry. This is the case, for instance, in the battles of Ticinus, Trebia and Cannae. More battle narratives, however, have no references at all to allied units, nor to the allied cavalry. Usually these battle descriptions refer to tactical units, such as maniples or hastati, but some are characterised by a total lack of specific terminology, only referring to the Romans, the army or to legions in a way that makes clear that the entire army is meant. In Livy's account

${ }_{18}$ Thus, Brunt 1971, op. cit. (n. 13), 625ff. Otherwise, Rawson 1991, op. cit. (n. 12).

${ }_{19}$ Polybius 6.21.7-10. On the interpretation, see recently N. Rosenstein, Rome at war. Farms, families and death in the Middle Republic (Chapel Hill 2004), 141. 
of the battle near the Metaurus in $207 \mathrm{Bc}$, for example, no reference whatsoever is given to allied infantry or cavalry, this despite the fact that the left and right wing (cornu) are regularly mentioned, while we know that the allied alae are usually stationed on the wings of the Roman battle formation. In short, in the majority of full-scale battle narratives, including all the major battles of the Hannibalic War, no mention is made of specific allied units. From this point of view, the majority of Livy's battle scenes closely resemble those of Polybius and paint the same picture of a uniform Roman army. This surely reflects the absence of details on allied units in the sources that Livy in these cases used.

Details concerning the allied contribution are confined to a limited number of battle narratives, all of which have in common other characteristic features, such as numbered legions and the regular mention of legates. Remarkable about this type of battle narratives, which are late-annalistic and can be securely ascribed to Valerius Antias, is the pattern of its occurrence in Livy's third, fourth and fifth decades. Fullscale narratives of this type are confined, first, to the Italian theatre of war during the central period of the Hannibalic War (213-207 BC) in books 25-27, and, second, to the wars in Spain and northern Italy from 205 BC onwards in book 29-41. The last case in which ethnic allied units and numbered legions occur in the extant books of Livy - the battle of Pydna (168 вс) - may be exceptional, since, on the one hand, there is clear Valerian material in Livy's battle narrative of Pydna, but, on the other hand, there is second-century evidence on specific allied units playing a prominent role at Pydna. ${ }^{20}$

The following table summarises the occurrences of specific allied units and/or numbered legions in Livy's full-scale battle narratives. In other words, these are the battles designated in this article as lateannalistic.

${ }^{20}$ A more detailed discussion of Livy's late-annalistic battle scenes and the reliance on Valerius Antias in these cases can be found in P. Erdkamp, 'Late-annalistic battlescenes in Livy (books 21-44)', Mnemosyne 59 (2006[a]), 525-563; id., 'Valerius Antias and Livy's casualty statistics', Studies in Latin literature and Roman history 13 (2006[b]), 166-182. In these publications it is shown that (1) Livy used the terminology of his sources on army units; (2) late-annalistic battle scenes are limited to particular periods and theatres of war; (3) characteristic features, such as numbered legions, allied units and details on legates, tribunes and centurions are common features of casualty reports and late-annalistic battle scenes; (4) battle scene and casualty report are often integrated; (5) nearly all casualty reports can be securely ascribed to Valerius Antias. 


\begin{tabular}{|c|c|c|c|c|c|c|}
\hline passage & year & event & source(s) & $\begin{array}{l}\text { numbered } \\
\text { legions }\end{array}$ & cives - socii & $\begin{array}{l}\text { list of casualties and } \\
\text { booty }\end{array}$ \\
\hline $\begin{array}{l}\text { Livy } \\
25.13 .11- \\
25.14 .11\end{array}$ & 213 & $\begin{array}{l}\text { attack } \\
\text { on Punic } \\
\text { camp near } \\
\text { Beneventum }\end{array}$ & & 3rd legion & $\begin{array}{l}\text { cohors Paeligna } \\
\text { cohors } \\
\text { sociorum et } \\
\text { civium legio }\end{array}$ & $\begin{array}{l}6000 \text { enemies killed, } \\
7000 \text { captured, } \\
\text { wagons and cattle }\end{array}$ \\
\hline $\begin{array}{l}\text { Livy } \\
25.21 .5- \\
25.21 .10\end{array}$ & 212 & $\begin{array}{l}\text { battle near } \\
\text { Herdonea }\end{array}$ & & 1st legion & ala sinistra & $\begin{array}{l}\text { of } 18,000 \text { men, only } \\
2,000 \text { escaped }\end{array}$ \\
\hline $\begin{array}{l}\text { Livy 26.5.7- } \\
26.6 .13\end{array}$ & 211 & $\begin{array}{l}\text { battle near } \\
\text { Capua }\end{array}$ & $\begin{array}{l}\text { 'auctores' } \\
\text { others: } \\
\text { no sig- } \\
\text { nificant } \\
\text { battle }\end{array}$ & 6th legion & $\begin{array}{l}\text { equites } \\
\text { legionum, } \\
\text { equites } \\
\text { sociorum }\end{array}$ & $\begin{array}{l}8000 \text { men from } \\
\text { Hannibal's army and } \\
3000 \text { Campanians } \\
\text { killed, } 15 \text { signa from } \\
\text { Hannibal, } 18 \text { from } \\
\text { the Campanians } \\
\text { captured }\end{array}$ \\
\hline $\begin{array}{l}\text { Livy 27.1.6- } \\
\text { 27.1.13 }\end{array}$ & 210 & $\begin{array}{l}\text { battle near } \\
\text { Herdonea }\end{array}$ & & $\begin{array}{l}5 \text { th }+6 \text { th } \\
\text { legion }\end{array}$ & sinistra ala & $\begin{array}{l}11 \text { tribuni militum } \\
13,000 \text { or } 7000 \\
\text { Romanorum } \\
\text { sociorumque killed }\end{array}$ \\
\hline $\begin{array}{l}\text { Livy 27.2.4- } \\
\text { 27.2.8 }\end{array}$ & 210 & $\begin{array}{l}\text { battle near } \\
\text { Numistro } \\
\text { (Italy) }\end{array}$ & & $\begin{array}{l}1 \mathrm{st}+3 \mathrm{rd} \\
\text { legion }\end{array}$ & $\begin{array}{l}\text { dextra }+ \\
\text { sinistra ala }\end{array}$ & \\
\hline $\begin{array}{l}\text { Livy } \\
27.12 .11- \\
27.12 .17\end{array}$ & 209 & $\begin{array}{l}\text { battle in } \\
\text { Apulia (I) }\end{array}$ & & 18th legion & $\begin{array}{l}\text { dextra ala } \\
\text { extraordinarii }\end{array}$ & $\begin{array}{l}2700 \text { civium } \\
\text { sociorumque killed } \\
\text { centuriones, tribuni } \\
\text { militum } \\
4 \text { signa of the ala }+ \\
2 \text { of the legion lost }\end{array}$ \\
\hline $\begin{array}{l}\text { Livy } \\
27.14 .2- \\
27.14 .14\end{array}$ & 209 & $\begin{array}{l}\text { battle in } \\
\text { Apulia (II) }\end{array}$ & & 18th legion & sinistra ala & $\begin{array}{l}8000 \text { enemies killed } \\
\text { and } 5 \text { elephants, } 1700 \\
\text { legionaries and } 1300 \\
\text { sociorum killed, many } \\
\text { civium sociorumque } \\
\text { wounded }\end{array}$ \\
\hline \begin{tabular}{|l} 
Livy \\
$27.41 .1-$ \\
27.42 .8
\end{tabular} & 207 & $\begin{array}{l}\text { battle near } \\
\text { Grumentum } \\
\text { (Lucania) }\end{array}$ & & $\begin{array}{l}1 \mathrm{st}+3 \mathrm{rd} \\
\text { legion }\end{array}$ & $\begin{array}{l}\text { equites legionis } \\
\text { dextra ala }\end{array}$ & $\begin{array}{l}8000 \text { enemies killed, } \\
700 \text { captured, } \\
9 \text { signa captured, } \\
4 \text { elephants killed, } \\
2 \text { elephants captured, } \\
500 \text { Romanorum } \\
\text { sociorumque victores } \\
\text { killed }\end{array}$ \\
\hline $\begin{array}{l}\text { Livy 29.2.4- } \\
\text { 29.2.18 }\end{array}$ & 205 & $\begin{array}{l}\text { battle } \\
\text { against } \\
\text { Ilergetes e.a. } \\
\text { (Spain) }\end{array}$ & & $\begin{array}{l}12 \text { th }+13 \text { th } \\
\text { legion }\end{array}$ & Romani equites & $\begin{array}{l}\text { 13,000 enemies } \\
\text { killed, } 1800 \text { captured, } \\
\text { 200 Romanorum } \\
\text { sociorumque }\end{array}$ \\
\hline
\end{tabular}




\begin{tabular}{|c|c|c|c|c|c|c|}
\hline passage & year & event & source $(\mathrm{s})$ & $\begin{array}{l}\text { numbered } \\
\text { legions }\end{array}$ & cives - socii & $\begin{array}{l}\text { list of casualties and } \\
\text { booty }\end{array}$ \\
\hline $\begin{array}{l}\text { Livy } \\
30.18 .2- \\
30.18 .15\end{array}$ & 203 & $\begin{array}{l}\text { battle } \\
\text { against } \\
\text { Mago } \\
\text { (Gallia } \\
\text { Cisalpina) }\end{array}$ & & $\begin{array}{l}\text { 11th, 12th } \\
\text { and 13th } \\
\text { legion }\end{array}$ & & $\begin{array}{l}5000 \text { enemies killed, } \\
22 \text { signa captured, } \\
2300 \text { Romans killed, } \\
\text { largely from the } 12 \text { th } \\
\text { legion, also tribunes } \\
\text { from the } 12 \text { th and } \\
\text { 13th legion }\end{array}$ \\
\hline $\begin{array}{l}\text { Livy } \\
31.21 .5^{-} \\
31.22 .2\end{array}$ & 201 & $\begin{array}{l}\text { battle } \\
\text { against Boii } \\
\text { (Gallia Cis.) }\end{array}$ & & & $\begin{array}{l}\text { dextra ala } \\
\text { equites } \\
\text { legionum } \\
\text { equitatus } \\
\text { sociorum }\end{array}$ & $\begin{array}{l}35,000 \text { enemies killed } \\
\text { or taken capture, } \\
70 \text { signa and } 200 \\
\text { wagons captured, } \\
2000 \text { Romanorum } \\
\text { sociorumque killed }\end{array}$ \\
\hline $\begin{array}{l}\text { Livy } \\
34.14 .1- \\
34.15 .9\end{array}$ & 194 & $\begin{array}{l}\text { attack on a } \\
\text { city (Spain) }\end{array}$ & $\begin{array}{l}\text { Valerius } \\
\text { Antias } \\
\text { Cato } \\
\text { only says } \\
\text { 'many' } \\
\text { (on casu- } \\
\text { alties } \\
\text { etc.) }\end{array}$ & 2nd legion & $\begin{array}{l}\text { equites } \\
\text { Romanorum } \\
\text { dextrae alae }\end{array}$ & 40,000 enemies killed \\
\hline $\begin{array}{l}\text { Livy } \\
34.46 .7- \\
34.47 .8\end{array}$ & 194 & $\begin{array}{l}\text { battle } \\
\text { against Boii } \\
\text { (Gallia Cis.) }\end{array}$ & & $\begin{array}{l}\text { 2nd and } \\
\text { 4th legion }\end{array}$ & $\begin{array}{l}\text { cohors extra- } \\
\text { ordinaria }\end{array}$ & $\begin{array}{l}\text { 19,000 enemies } \\
\text { killed, } 5000 \text { Romani } \\
\text { killed }\end{array}$ \\
\hline $\begin{array}{l}\text { Livy } 35.4 .6^{-} \\
\text {35.5.14 }\end{array}$ & 193 & $\begin{array}{l}\text { battle } \\
\text { against Boii } \\
\text { (Gallia Cis.) }\end{array}$ & & 2nd legion & $\begin{array}{l}\text { sinistra ala } \\
\text { extraordinarii } \\
\text { dextra ala } \\
\text { equites } \\
\text { legionum } \\
\text { equites alarum }\end{array}$ & $\begin{array}{l}\text { 14,000 enemies } \\
\text { killed, } 1092 \text { captured } \\
\text { (also } 721 \text { horsemen } \\
\text { and } 3 \text { leaders), } \\
212 \text { signa and } 102 \\
\text { wagons captured, } \\
5000 \text { Romani and } \\
\text { socii killed, including } \\
\text { praefecti socium and } \\
\text { tribuni militum of the } \\
\text { 2nd legion }\end{array}$ \\
\hline $\begin{array}{l}\text { Livy } \\
\text { 39.30.9- } \\
39.31 .16\end{array}$ & 185 & $\begin{array}{l}\text { battle on } \\
\text { the Tagus } \\
\text { (Spain) }\end{array}$ & & $\begin{array}{l}\text { 5th and } \\
\text { 8th legion }\end{array}$ & \begin{tabular}{|l} 
equites \\
legionum \\
equites \\
sociorum \\
Romani equites
\end{tabular} & $\begin{array}{l}4000 \text { of } 35,000 \\
\text { enemies escaped, } \\
133 \text { signa captured, } \\
600 \text { romani sociique, } \\
150 \text { auxilia killed, } \\
\text { including } 5 \text { tribuni } \\
\text { militum and some } \\
\text { equites }\end{array}$ \\
\hline
\end{tabular}




\begin{tabular}{|c|c|c|c|c|c|c|}
\hline passage & year & event & source(s) & $\begin{array}{l}\text { numbered } \\
\text { legions }\end{array}$ & cives - socii & $\begin{array}{l}\text { list of casualties and } \\
\text { booty }\end{array}$ \\
\hline $\begin{array}{l}\text { Livy } \\
40.27 .1- \\
40.28 .6\end{array}$ & 181 & $\begin{array}{l}\text { battle in } \\
\text { Liguria }\end{array}$ & & $\begin{array}{l}\text { 1st }+3 \mathrm{rd} \\
\text { legion }\end{array}$ & $\begin{array}{l}\text { cohortes } \\
\text { extraordinarii } \\
\text { ala dextra }\end{array}$ & $\begin{array}{l}15,000 \text { enemies } \\
\text { killed, } 2500 \text { captured }\end{array}$ \\
\hline $\begin{array}{l}\text { Livy } \\
40.31 .1- \\
40.32 .7\end{array}$ & 181 & $\begin{array}{l}\text { battle } \\
\text { against } \\
\text { Celtiberians } \\
\text { (Spain) }\end{array}$ & & $\begin{array}{l}5 \text { th }+7 \text { th } \\
\text { legion }\end{array}$ & $\begin{array}{l}\text { ala sinistra } \\
\text { equites } \\
\text { extraordinarii }\end{array}$ & $\begin{array}{l}23,000 \text { enemies } \\
\text { killed, } 4700 \text { captured, } \\
500 \text { horses and } \\
88 \text { signa captured, } \\
200 \text { Romani } \\
\text { milites, } 830 \text { socium } \\
\text { Latini nominis, } \\
\text { 2400 auxiliarium } \\
\text { externorum killed }\end{array}$ \\
\hline $\begin{array}{l}\text { Livy } 41.1 .5^{-} \\
41.4 .8\end{array}$ & 178 & $\begin{array}{l}\text { attack by } \\
\text { Histri (Italy) }\end{array}$ & & $\begin{array}{l}\text { 2nd + 3rd } \\
\text { legion }\end{array}$ & $\begin{array}{l}\text { cohors } \\
\text { Placentina } \\
\text { equitatus } \\
\text { legionis }\end{array}$ & $\begin{array}{l}8000 \text { enemies killed, } \\
\text { none captured, } \\
237 \text { victores killed }\end{array}$ \\
\hline $\begin{array}{l}\text { Livy } \\
44.40 .4- \\
\text { (lacuna) } \\
44.42 .8\end{array}$ & 168 & $\begin{array}{l}\text { battle of } \\
\text { Pydna }\end{array}$ & & 2nd legion & $\begin{array}{l}\text { cohors } \\
\text { Marrucina, } \\
\text { Paeligna } \\
\text { turmae } \\
\text { Samnitium } \\
\text { equitum } \\
\text { cohors } \\
\text { Firmana, } \\
\text { Vestina, } \\
\text { Cremonensis } \\
\text { turmae } \\
\text { equitum } \\
\text { Placentina et } \\
\text { Aesernina } \\
\text { alae sociorum }\end{array}$ & $\begin{array}{l}20,000 \text { enemies } \\
\text { killed, } \\
11,000 \text { captured, } \\
100 \text { victores killed, } \\
\text { largely Paeligni }\end{array}$ \\
\hline
\end{tabular}

The important point is that all the information that can be found on the tactical functioning of allied units is confined to a limited number of battles narratives, almost all deriving from the same late-annalistic source.

In most cases, allies are referred to as the extraordinarii or the left or right ala. See, for instance, Livy's account of a battle against the Boii in 193 вG:

The second legion was sent forward and the extraordinarii relieved. Then the battle was restored, since fresh troops, a legion with full ranks, had entered the fight. The ala sinistra was withdrawn from the battle and the ala dextra took its place in the battle-line. (35.5.6) 
As usual, Livy ends his account of the battle with a detailed list of casualties and booty, the latter including military standards and wagons. He notes that among the Roman dead, there were many allied prefects and military tribunes from the 2nd legion.

There are similar cases when Livy briefly mentions a battle without an actual narrative. Two cases are especially interesting: in book 39, Livy mentions an attack by Ligurians, as a result of which not only 4000 Roman soldiers were killed, but 3 military standards from the 2nd legion and 19 standards of the allies were lost. ${ }^{21}$ Similarly, in book 42 Livy says that some authors mentioned a battle against Perseus:

There are those who declare that a great battle was fought on that day, that 8,000 of the enemy were killed, among them Sopater and Antipater, officers of the king, that there were taken alive about 2,800 men, and that 27 military standards had been taken. Nor was the victory bloodless, they say; more than 4,300 of the consul's army fell, and five standards of the sinistra ala were lost. (Livy 42.66.9-10)

These instances clearly show that the numbered legions, the details concerning allied contingents and the loss of military standards are closely integrated. We can take this relation between numbered legions and allied contingents even further, since all the battle scenes having details on allied units also have numbered legions. Livy's battle accounts with numbered legions, details concerning allied units and military standards in the lists of casualties and booty can be related to Valerius Antias. We may be certain that Valerius Antias was Livy's only source for battle accounts of the late-annalistic type. ${ }^{22}$

Livy clearly distrusted some of the battles he found in the work of Valerius Antias and the figures provided by this late-republican annalist. Sometimes he dismisses outright the obvious falsehoods in his predecessor's account, but on occasion he summarises or copies the information he found, telling the reader of the origin of this information, and leaving it to the readers' judgement whether to trust it or not. ${ }^{23}$ The damaging depiction by Livy of Valerius Antias does not inspire confidence in the details on specific allied units that we find in this context.

21 Livy 39.20.6-8.

22 Erdkamp 2006[a+b], op. cit. (n. 20).

${ }^{23}$ Livy 30.3.6; 30.29.7; 32.6.5ff.; 37.34.5; 38.48.1ff.; 42.11.1; 44.13.12ff. 
Livy's casualty figures for the battle of Pydna are cited as evidence by W.V. Harris for his statement that "the allies suffered more heavily in combat than the citizen legions". ${ }^{24}$ Besides Pydna, two other instances support this hypothesis, both dealing with battles fought against the Celtiberians in Spain (in 181 and 180 Bc). In 40.32.7, Livy writes that 200 Roman soldiers were killed, 830 allies and Latins, and 2400 'external auxiliaries'. The number of casualties reflects the previous account: allied troops and 6000 Spanish auxiliaries played a special role during the battle. In 40.40.13, 472 Roman soldiers, 1019 allies and Latins and 3,000 auxiliary troops were killed. It is only rarely that Livy gives separate numbers of casualties for citizen and allied troops. I can only add one further instance, which Harris, unsurprisingly, fails to mention: 1700 legionaries and 1300 allies fell during the second battle of Marcellus in Apulia in 209 BC (Livy 27.14.14). If these figures are somehow based on official data, it is surprising that only four out of approx. 80 cases distinguish between citizens and allies. Many cases say 'Romans and allies,' but give no separate figures. It is hard to explain why figures specifying citizens and allies were only available for Pydna and three obscure battles in Spain and Italy. Such detail is worrying. All of these four instances include military standards among the booty. In view of what we have seen on the reliability of late-annalistic battle statistics, we should conclude that Harris' statement is founded on shaky evidence.

\section{Livy and Plutarch on the battle of Pydna}

In $168 \mathrm{BC}$, the final year of the Third Macedonian War, the armies of the two powers camped near Pydna, the one under the command of L. Aemilius Paullus, the other led by the Macedonian king Perseus.

There was a stream of no great size nearer the camp of the enemy, from which both the Macedonians and the Romans were drawing water after posting guards on either bank in order to accomplish this mission safely. There were two cohorts on the Roman side, a Marrucinian and a Paelignian, and two troops of Samnite cavalry under the command of the legate Marcus Sergius Silus. Another fixed outpost was stationed before the camp under the legate Gaius Cluvius, composed of three

${ }^{24}$ Harris 1984, op. cit. (n. 6), 97. Likewise, A. Keaveney, Rome and the unification of Italy (London 1987), 15. 
cohorts, from Firmum, the Vestini and Cremona respectively, and two troops of cavalry from Placentia and Aesernia. While there was quiet at the river, since neither side took the offensive, about the ninth hour a baggage-animal shied from the hands of his grooms and escaped towards the other bank. While three soldiers were chasing him through the water, which was about knee-deep, two Thracians dragged the animal from midstream to their bank. The soldiers pursued them, killed one, recaptured the animal, and retired to their post. There was a guard of eight hundred Thracians on the Macedonian bank At first a few of these, angry at the killing of their fellow-countryman before their eyes, crossed the river in pursuit of the killers, then more went, and finally the whole force, and the guard...(Livy 44.40.4ff.)

There is a big lacuna in our text, since two pages of the manuscript are missing, but the further description makes clear that the allied troops came to blows with the forces on the Macedonian side of the river, leading to a fierce battle. The cohorts of Paeligni and Marrucini fearlessly attacked the Macedonian phalanx. The Roman citizen-forces consisted of the 1st and 2nd legion. When Livy's narrative resumes, the 2nd legion attacked the centre of the Macedonian force. On the right wing, Roman elephants and allied troops put the Macedonian wing to flight, which was the first step to a brilliant Roman victory.

The importance of this passage lies in the survey of allied contingents on the Roman side, consisting of infantry cohorts from the Marrucini, Paeligni, Firmum, the Vestini and Cremona, and cavalry units of Samnium, Placentia and Aesernia.

Livy's battle narrative of Pydna contains elements that are clearly late-annalistic, such as the numbered legions. The presence of numbered legions in Livy's account of Pydna shows that Livy did not simply paraphrase Polybius' narrative of the battle, as he did for instance on Cynoscephalae (197 BC) and Thermopylae (191 BC). ${ }^{25}$ There are two reasons for this assumption: Polybius never has numbered legions in his battle accounts, and numbered legions make only one appearance in battles in the East, viz. at Pydna. As we have seen above, numbered legions are closely connected to Valerius Antias. In fact, they may be seen as characteristic of Antias. Hence, Livy's account partly stems from Antias.

On the other hand, we may not simply assume that the allied contingents originated in the work of Antias. The parallel account of the

${ }^{25}$ Livy 33.7.4; 36.18.1. 
battle of Pydna in Plutarch's life of Aemilius Paullus also mentions Paeligni and Marrucini. Plutarch refers to three second-century sources in his account of the battle: besides Polybius, he mentions the Roman Scipio Nasica, who was present during the battle, and a pro-Macedonian author called Poseidonius, who wrote a biography of Perseus. Should we then assume that Livy's account of Pydna is partly Polybian and that the Paeligni and Marrucini in Plutarch's narrative were already there in Polybius? Moreover, should we then assume that the other allied units were also part of a second-century source? These questions require a detailed comparison of Plutarch's and Livy's account of the battle. ${ }^{26}$

(1) Plutarch (Aem. 1) notes some disagreement about the start of the battle: some say that Aemilius Paullus himself devised a scheme for making the enemy start the battle. An unbridled horse, driven into the river by the Romans, caused the attack. Others write (Plutarch says) that Thracians, chasing Roman beasts of burden, started the battle. Plutarch's sources agree with Livy on the nature of the events that started the battle. Plutarch's second version closely resembles Livy's narrative.

(2) Livy (44.42.2) briefly notes that, after the Macedonian phalanx had been defeated, the king was the first to flee. This is in disagreement with Polybius' version as mentioned by Plutarch (18.2). According to Polybius, Perseus rode to the city as soon as the battle began under the pretence of sacrificing to Heracles, while Poseidonius gives a favourable account of the king's behaviour.

(3) According to Plutarch (20.1-3), when the Romans unsuccessfully attacked the Macedonian phalanx, the commander of the Paelignians, Salvius, hurled the standard of his unit among the enemy.

Then the Paelignians, since among the Italians it is an unnatural and flagrant thing to abandon a standard, rushed on towards the place where it was, and dreadful losses were inflicted and suffered on both sides.

However, the shields and swords of the Romans were of no use against the long spears of the Macedonians. The Paelignians and Marrucini fought 'with animal fury', but their first line was cut to pieces and the rest driven back. Plutarch only mentions Poseidonius in this context, but the story was probably also in Polybius and/or Nasica. Livy does

\footnotetext{
${ }^{26}$ Cf. H. Nissen, Kritische Untersuchungen über die Quellen der vierten und finften Dekade des Livius (Berlin 1863), 300ff.
} 
not have this story, but it may have been in the lacuna. Noteworthy is that Plutarch has no earlier mention of the Paeligni and Marrucini.

(4) The analysis of the Roman victory in both accounts is similar, but with significant differences. Livy assigns a crucial role to allied units and elephants. Plutarch does not mention them. Plutarch has a detailed tactical analysis, claiming that the rough terrain caused the formation of the Macedonian phalanx to break down, which then fell victim to the superior weaponry of the Romans in close combat. This analysis closely resembles Polybius' comparison of the strengths and weaknesses of the Roman legions and Macedonian phalanx in battle. ${ }^{27}$ The niceties of Plutarch's tactical analysis are missing in Livy's account. It is impossible to say whether this is the result of his lack of interest in such matters, or because the source Livy used did not have these elements.

(5) Livy notes that the Romans killed 20,000 Macedonians and lost about 100 men, most of whom were Paelignians. Plutarch differs from Livy in the number of Macedonians killed (25,000). The number of Roman dead was 100 according to Poseidonius and 80 according to Nasica. No figure for Polybius is given. We may observe, however, that in his extant battle accounts, Polybius never specifies particular groups among the Roman casualties.

All in all, there is little to support the hypothesis that Livy's account is largely Polybian, apart from the fact that normally Livy relies on his Greek predecessor for Greek matters. The Paeligni and Marrucini clearly are part of a tradition that was already present in the second century BC and it is possible that they occurred in Polybius' narrative. However, it is impossible to say which elements were already present in the second-century sources, and which elements derived from Valerius Antias. Cohorts from Firmum, the Vestini and Cremona, and cavalry units from Samnium, Aesernia and Placentia play no role in what remains of Livy's battle narrative and do not occur in Plutarch's account. A firm conclusion is not possible, but we may point out that allied units are not normally a feature of Polybius, while they are of Valerius Antias.

${ }^{27}$ Polybius 18.31. 
Allied cohorts in Sallust's Jugurthine War

Secure evidence for ethnic allied units does not emerge before the time of Marius, but it is sparse: in the Jugurthine War, Marius commanded a cohors Paeligna (Bell. Jug. 105.2), while two cohorts from Camerinum fought at his side during the battle of Vercellae against the Cimbri (Gicero, Balb. 46; Valerius Maximus 5.2.8). In the latter case, we are not informed about their composition or role, since it is only said that these men were rewarded Roman citizenship by Marius for their bravery. ${ }^{28}$

We learn more from Sallust's Jugurthine War, which contains five references that are relevant to our discussion.

(1) Under the command of Aulus Postumius Albinus (brother of the consul Spurius), a cohors Ligurum, two turmae Thracum and some legionaries were bribed by the Numidian king and defected to his side (38.6).

(2) The consul Metellus sent four cohortes Ligurum as a garrison to Leptis (77.4). These passages show that we are not dealing with an innovation by Marius.

(3) Under the command of Marius, a Ligurian soldier - ex cohortibus auxiliariis miles - points the way to a position above the Numidians (93.2). Auxilia is a term used for specialised troops, usually non-Italic, such as light-armed units, slingers or archers. Hence, the Ligurian cohorts were not part of the 'normal' allied infantry consisting of socii ac nomen Latinum that fought at the side of the Roman legionaries.

(4) During a march, Marius kept his army ready for combat. Aulus Manlius commanded slingers, archers and the cohortes Ligurum on the left (100.2). This confirms the conclusion drawn from passage nr. 3.

(5) When sent to king Bocchus by Marius, Sulla was accompanied by horsemen, Balearic slingers, archers and a light-armed cohors Paeligna (cum velitaribus armis - 105.2). In view of the previous passages and the nature of the other troops accompanying Sulla, the light-armed cohors Paeligna should be interpreted as an auxiliary unit of the same nature as the Ligurian cohorts.

${ }^{28}$ Plutarch, Marius 28.2 does not mention cohorts, but talks about 1,000 men from Camerinum. 
The presence of auxiliary cohorts should be seen in the light of developments in the Roman army in the late second century BG. First, legionary cohorts are solely mentioned by Sallust as a unit in relation to the march or foraging. At first, cohorts had no function in combat. The maniple remained the tactical unit of the heavy infantry. In Marius' combatready marching order (passage nr. 3), for instance, the core consisted of maniples commanded by tribunes. Interesting is the Polybius-like disregard for the distinction between Roman soldiers and officers and the allied infantry and their prefects, which makes one wonder whether Sallust's 'legion' is used as broadly as Polybius.' The main point, however, is that the cohort had not yet replaced the maniple as a tactical unit of the Roman and allied heavy-infantry. ${ }^{29}$

Secondly, in the late second century Ba, the light-armed soldiers (velites) disappeared as part of the legions, which was a logical consequence of the fact that Roman soldiers were being armed at the cost of the state. ${ }^{30}$ The troops in citizen and allied contingents became increasingly uniform, consisting of heavy-armed infantry. From this point of view, there was little difference between the army of Marius and that of Caesar, except for the fact that the heavy infantry after the Social War was solely manned by citizen-legionaries. The disappearance of the socii ac nomen Latinum made no difference to the functioning of the Roman army, which in itself proves the uniformity in organisation and functioning at least in the late second century BC. At the time of the Jugurthine War and already before Marius took command, the role of the velites was largely taken over by foreign units, such as Thracian and Ligurian mercenaries. It is interesting to see that Paelignians had a similar role, which may be related to the long tradition of Italic mountain-peoples to find employment as mercenaries. To conclude: besides the core of Roman and allied heavy-infantry units, the Roman army of the late second century BC consisted of special troops of light-armed infantry, slingers and archers, which were organised in cohorts. ${ }^{31}$ The cohors Paeligna in Sallust probably was a light-armed

${ }^{29}$ I hope to have shown that Livy's regular use of cohorts regarding the wars in Spain is of little consequence. Contra M.J.V. Bell, 'Tactical reform in the Roman republican army', Historia 14 (1965), 405.

${ }_{30}$ Plutarchus, C. Gracchus 5.1. Recently, P. Erdkamp, 'The transformation of the Roman army in the second century Bc', in T. Naco del Hoyo et al., eds., War and territory in the Roman world (Oxford 2006), 41-51. $57 \mathrm{ff}$.

${ }^{31}$ L. Keppie, The making of the Roman army. From republic to empire (London 1998), 
auxiliary unit. The cohorts from Camerinum may have functioned in a similar way.

\section{Loyal allies, former foes and new citizens}

A legitimate question to ask is why a late-republican historian like Valerius Antias would bother to add details about ethnic units. What interest would he have in mentioning allied units, when his second-century predecessors did not? Three elements may be given as part of the answer. For one, giving much detail was a means employed in late republican historiography to boost one's credibility. Valerius Antias established his character as a serious and reliable historian by giving many details in a formulaic manner, including lots and lots of figures. ${ }^{32}$ Even Livy wonders how Antias dared to give the exact number of enemies killed regarding battles fought in the fifth century BG. ${ }^{33}$ The most noteworthy fact, however, is that Livy, despite all his criticism of Valerius Antias, includes the latter's information on casualties, captives and booty. Such figures had become part of the historiographical tradition, a natural element of the genre. Valerius Antias undoubtedly improved on his predecessors by giving yet more numbers. ${ }^{34}$ The same applies to details concerning individuals and units in some of Livy's battles. Instead of anonymous actions of Roman soldiers, as in the works of Polybius and a large part of Livy's battle accounts, we see individual tribunes and centurions performing their heroic feats on the battle field. The same tendency lies behind the mentioning of particular units, such as numbered legions or ethnic units.

32 Timpe 1979, op. cit. (n. 2), 103ff.; S.P. Oakley, A commentary on Livy I (Oxford 1997), 75f.; U. Walter, 'Opfer ihrer Ungleichzeitigkeit. Die Gesamtgeschichten im ersten Jahrhundert v.Chr. und die fortdauernde Attraktivität des annalistischen Schemas', In U. Eigler et al., eds., Formen römischer Geschichtsschreibung von den Anfängen bis Livius (Darmstadt 2003), 149ff.

${ }^{33}$ Livy 3.5.13. Cf. Brunt 1971, op. cit. (n. 13), 695; R.A. Laroche, 'Valerius Antias and his numerical totals. A reappraisal', Historia 26 (1977), 359; Id. 'Valerius Antias as Livy's source for the number of military standards captured in battle in books I-X', Classica et mediaevalia 35 (1984), 95; G. Forsythe, 'Dating and arranging the Roman history of Valerius Antias', in V.B. Gorman and E.W. Robinson, eds., Oikistes. Studies in constitutions, colonies and military power in the ancient world (Leiden 2002), $110 \mathrm{f}$.

${ }^{34}$ Laroche 1984, op. cit. (n. 33), 102. 
A second part of the answer must have been the increased integration of Italic families in the political and cultural elite of Rome. ${ }^{35}$ Valerius Antias, just like Livy, did not come from Rome. There may be little evidence to support the supposition of Dieter Timpe that Valerius Antias and Claudius Quadrigarius were members of the Italic municipal aristocracy, but we may agree with him that the first-century historians wrote for a widening audience that increasingly included leading families of the former allies. ${ }^{36}$ Not only in politics, but also in literature and art, we see individuals from the municipal aristocracies coming to the fore. The losses amongst the elite of Rome in the age of Sulla as a result of political prosecutions and civil wars were partly compensated by the influx of leading Italic families. ${ }^{37}$ These families had an outlook on Roman history that was not dominated by the city of Rome. While Polybius and the early Roman historians emphasized the homogeneous nature of the Roman army, in which Romans and allies were fully integrated, it suited the interests of many first-century readers to spell out the role that allies had served in Roman history. Later authors celebrated the Italian peoples even in their role as opponents of Rome. Take, for example, the following lines in which Ovid (Am. 3.15.7-10) stresses his Paelignian background:

Mantua rejoices in her Vergil, Verona in her Catullus.

It is of the Paelignian race that I shall be said to be the glory, the race whose desire for freedom had compelled it to take up honourable arms,

when anxious Rome feared the allied bands.

Rome may have feared the Paeligni, but their cause was freedom and their struggle thus honourable. ${ }^{38}$ An interesting parallel is offered by

35 Brunt 1988, op. cit. (n. 1), $117 \mathrm{ff}$; Gabba 1989, op. cit. (n. 1), $210 \mathrm{ff}$. However, H. Mouritsen, Italian unification. A study in ancient and modern historiography (London 1998), 59ff. is sceptic about the degree of integration or romanisation: "When looking at Augustan Italy one is immediately struck by the remarkable homogeneity achieved in most areas: language, urbanisation, and monumentalisation, institutions, cult, artistic production, burial practice, epigraphic habits, etc. The obvious romanisation encountered in this period contrasts sharply with the barely traceable Roman influence prior to the Social War" (p. 81).

${ }^{36}$ Timpe 1979, op. cit. (n. 2), 113 f. Cf. T.P. Wiseman, Clio's cosmetics. Three studies in Greco-Roman literature (Leicester 1979), 23; K.-E. Petzold, 'Zur Geschichte der römischen Annalistik', in W. Schuller, ed., Livius (Konstanz 1993), 170f.; Walter 2003, op. cit. (n. 32), 141 .

37 Galsterer 1976, op. cit. (n. 2), 145.

38 The example was taken and quoted from M. Pobjoy, 'The first Italia', in E. Herring and K. Lomas, eds., The emergence of state identities in Italy in the first millennium $B C$ 
the historian Velleius Paterculus, who declared that the cause of the rebellious allies in the Social War had been just. ${ }^{39}$

The fortune of the Italians was as cruel as their cause was just. For they were seeking citizenship in the state whose power they were defending by their arms. Every year and in every war they were furnishing a double number of men, both of cavalry and of infantry, and yet were not admitted to the rights of citizens in the state which, through their efforts, had reached so high a position that it could look down upon men of the same race and blood as foreigners and aliens. (Vell. Pat. 2.15.2.) ${ }^{40}$

To strengthen his point, he claimed that the allies had provided two soldiers for every citizen soldier. This statement is certainly wrong, but it served his purpose. ${ }^{41}$ It agreed with the Italic identity of the historians and that of many of their readers to pay attention to the non-Roman contribution to Roman history. The relationship between identity and historiography was, of course, no new phenomenon: one of the functions of Roman historiography was to define and characterise Roman identity. Virtues and moral superiority were central to the Roman understanding of themselves and their role in world history. This understanding is reflected in the emphasis on moral exempla in Roman historiography. ${ }^{42}$ It was only a natural development that, when the word 'Roman' expanded in meaning and steadily began to incorporate Italic peoples, historiography had to incorporate the identity of these new 'Romans' as well.

The growing tension between Romans and allies at the end of the second century BC, culminating in the Social War, surely increased the interest in the role of the allies in Roman history. As E. Gabba stated:

(London 2000), 197. See also G. Bradley, 'Iguvines, Umbrians and Romans. Ethnic identity in central Italy', in T.J. Cornell and K. Lomas, eds., Gender and ethnicity in ancient Italy (London 1997), 62 on the "strong sense of regional heritage in the work of the poet Propertius, who was a native of Asisium [Umbria]".

39 This notwithstanding the fact that his greatgrandfather, Minatius Magius from Aeculanum, had remained loyal to Rome, had raised a legion (!) among the Hirpini and fought successfully against the insurgents. He was rewarded Roman citizenship. Velleius Paterculus 2.16.2. M.H. Crawford, 'Italy and Rome from Sulla to Augustus', Cambridge Ancient History X (Cambridge 1996), 417f. observes: "Velleius was well aware that the Italian cause was just, but that loyalty to Rome was an overriding obligation".

${ }^{40}$ Pobjoy 2000, op. cit. (n. 38), 190: "Velleius' presentation of the Italians as effectively Roman in all but formal status."

${ }^{41}$ Brunt 1988, op. cit. (n. 1), 126: "This sounds like a relic of allied propaganda." Cf. Harris 1984, op. cit. (n. 6), 96, 99f.; Bradley 1997, op. cit. (n. 38), 60.

${ }^{42}$ B. Feichtinger, 'Ad maiorem gloriam Romae. Ideologie und Fiktion in der Historiographie des Livius', Latomus 51 (1992), $16 \mathrm{ff}$. 
"The allies became increasingly aware that they had helped create an empire in which they enjoyed only part of the fruits." ${ }^{43}$ I suggest that we see some of the emphasis on the allied role in Rome' glorious past in Livy's account of Roman battles and of the Roman war-effort in general. Two noteworthy examples may be highlighted: the Latin colony of Fregellae and the allied people of the Paeligni.

Every educated first-century Roman will have been aware of the fact that Fregellae, founded as a Latin colony in 328 BC, was taken and destroyed by a Roman army in 125 BG, after part of its citizens had expressed serious discontent with Rome and possibly even had advocated revolt. ${ }^{44}$ A contrasting picture of Fregellan loyalty arises from a few events during the Hannibalic and later wars as described by Livy. In the year $211 \mathrm{BC}$, Hannibal tried to deflect some of the legions besieging Capua and marched towards Rome. In an attempt to slow down Hannibal's approach, and thus offering precious time to the Roman authorities, the citizens of Fregellae demolished the bridge across the Liris. Furthermore, a messenger from Fregellae, travelling day and night and apparently bringing the first news of Hannibal's approach, caused great panic in Rome. ${ }^{45} \mathrm{~A}$ few years later, a great crisis emerged in Rome when 12 Latin colonies refused to contribute any more troops, saying that their manpower and resources were exhausted by the past years of fighting. The consuls summoned the envoys from the remaining 18 colonies and asked them to elucidate their position.

On behalf of the eighteen colonies Marcus Sextilius of Fregellae replied that they had soldiers in readiness according to the treaty, and would give more if more were needed, and would exert themselves to do whatever else the Roman people might command and desire. (Livy 27.10.3.)

${ }^{43}$ Gabba 1989, op. cit. (n. 1), 223.

${ }^{44}$ On the causes of the rebellion of Fregellae, Keaveney 1987, op. cit. (n. 24), 64ff;; Mouritsen 1998, op. cit. (n. 35), 118f. Galsterer 1976, op. cit. (n. 2), 179ff. argues that many of its citizens were settled in the citizen-colony Fabrateria Nova, which replaced Fregellae. In other words, the punishment was not as harsh at it seems, since the destruction of the 'political' unity of Fregellae does not imply the destruction of its entire population. Similar, E. Gabba, 'Rome and Italy: the Social War', Cambridge Ancient History IX (Cambridge 1994), 105. However, Brunt 1988, op. cit. (n. 1), 96f. disagrees, pointing out "of this there is no evidence" (p. 97). For the image of the peoples of the Central Apennines, see E. Dench, From barbarians to new men. Greek, Roman and modern perceptions of peoples of the Central Apennines (Oxford 1995).

${ }^{45}$ Livy 26.9.3-6. Oakley 1997, op. cit. (n. 32), 83: these events are probably unhistorical. 
The prominence of the city und its unwavering support of Rome could not have been expressed more clearly. Their next appearance is during a famous disaster: when Marcellus was killed by a troop of Numidians, he was accompanied by 180 Etruscan and 40 Fregellan horsemen. The negative outcome of this event actually emphasizes the courage and loyalty of the Fregellani, as Livy carefully distinguishes between the conduct of the Etruscans and that of the Fregellans. While the Etruscans all fled when the enemy appeared, the Fregellans defended Marcellus until the end. Seeing that Marcellus was mortally wounded, the few who survived turned to flight with Marcellus's wounded colleague and his son. ${ }^{46}$ No reproach is possible here. Finally, Livy mentions a particular version on the capture of the son of P. Scipio from an unnamed source: he had been captured by the enemy during the War against Antiochus III, while being accompanied by a cavalry contingent from Fregellae. He had fallen from his horse and had been captured together with a few horsemen, so it does not appear that the fault lie with the horsemen from Fregellae. ${ }^{47}$ It was the wealthier people among the allies that served in the cavalry. Hence, it is the upper class of Fregellae that is presented in a very favourable light in these anecdotes and events.

A second example is provided by the Paeligni, who were famous in the first century for the fact that their central town Corfinium had been renamed Italica at the start of the Social War and had served as the capital of the revolt. Their first great appearance in the third decade is during the Roman attack on a Punic camp near Beneventum in 213 BC. Interestingly, this battle, occurring early in book 25, is the first of the late-annalistic type in the third decade, characterised as it is by numbered legions, legates, prefects - and, of course, an ethnic allied unit. The latter plays a prominent role when the Roman consul Fulvius, depicted as weak and indecisive, orders his troops, who are eager to fight, to retreat.

Nearest to the enemy happened to be a Paelignian cohort, whose prefect Vibius Accaus seized the banner and threw it over the enemy's earthwork.

${ }^{46}$ Livy 27.27.6f. Cf. D.-A. Kukofka, Süditalien im Zweiten Punischen Krieg (Frankfurt am Main 1990), 116. To interpret these events as evidence of the anti-Roman attitude of the Etruscan horsemen really goes too far. Harris 1971, op. cit. (n. 2), 137f. contra D.W.L. van Son, 'The disturbances in Etruria during the Second Punic War', Mnemosyne 16 (1963), 268; A.J. Pfiffig, 'Die Haltung Etruriens im 2. punischen Krieg', Historia 15 (1966), 201f.

${ }^{47}$ Livy 37.34.6. 
Then, with a curse upon himself and the cohort, if the enemy should get possession of that banner, he was himself the first to dash over the trench and wall into the camp. And already the Paelignians were fighting inside the wall, when from the other side of the camp, while Valerius Flaccus, tribune of the soldiers of the third legion, was reproaching the Romans for their cowardice in yielding to allies the honour of capturing the camp.... (Livy 25.14.4-5.)

The centurion of the first maniple follows the Paelignian's example, takes his unit's standard (signum) and leads his troops into the fight. After the victory, both officers are rewarded for their valour. Can it really be coincidence that the military tribune - whose role, by the way, is perfectly superfluous - is named Valerius? ${ }^{48}$ In any case, the numbered legions, ethnic unit and prominent role of military standards all point in the same direction. We have already seen that the Paeligni play a crucial role in Livy's account of the battle of Pydna, which is reflected by the fact that most of the casualties on the Roman side were Paelignians. Finally, we may note that in 205 Bc, many Paelignians, besides Marsians and Marrucini, volunteer for Scipio's fleet. ${ }^{49}$

It seems remarkable at least that peoples, who had been bitter enemies just a few generations before, are depicted in Livy's work in such a positive way. One may also add the heroic action of Oblacus Volsinius, leader of the Frentani, who in the battle of Heracleia cut his way through the ranks until he was face to face with Pyrrhus and nearly managed to kill him (Dionysius 19.12; Plutarch, Pyrrh. 16.8-10). All these peoples and communities revolted against Rome at the start of the first century. ${ }^{50}$ Of course, the former foes of the Social War are not the only ones that are depicted positively. Placentian knights and units from Praeneste, Firmum or Cremona are also mentioned, for

${ }^{48}$ On the tendency of Valerius Antias to introduce Valerii in major roles throughout early Roman history, T.P. Wiseman, Roman drama and Roman history (Exeter 1998), $77 \mathrm{ff}$. Undoubtedly he also included Valerii in minor roles in later events.

${ }^{49}$ Livy 28.45.19. One may add that, in 196 BC, a cohors Marsorum bears the brunt of a battle against the Insubres (Livy 33.36.10), and that, according to one tradition, a Samnite-lead force saved the army of Minucius from destruction by Hannibal's troops in 217 BC (22.24.10ff.). Note that in the first case, Valerius Antias is mentioned as the source of the casualty figures. Regarding the same passage, A. Ziolkowski, 'Credibility of numbers of battle captives in Livy, books XXI-XLV', La Parola del Passato 45 (1990), 27 concludes that 'no battle was fought at all'.

${ }^{50}$ In Per. 72, a list is given of seven peoples that revolted against Rome, which included the Picentes, Vestini, Marsi, Paeligni, Marrucini, Samnites and Lucani. Cf. Appian, Bell. civ. 1.39. E.T. Salmon, 'Notes on the Social War', Transactions and Proceedings of the American Philological Association 89 (1958), 159ff.; Galsterer 1976, op. cit. (n. 2), $189 f$. 
instance, but it would be hard in these cases to show the same deliberate effort to depict the allies in a favourable light. It is impossible to say whether the stories in favour of the rebellious allies were invented when the conflict between Rome and some of her allies emerged, or possibly at a later date, or whether there were actually local traditions that were transmitted somehow to Roman historiography. In the case of Fregellae and the Paeligni, I want to suggest that the above passages are meant as a vindication of these prominent former enemies. The existence of such traditions in the wake of the Social War may be seen as the third element that partly explains the prominent role of the allies in Livy's late-annalistic battles.

\section{Conclusion}

In Polybius' view, the allies fought side by side with citizen troops in a uniformly organised army. In his battle narratives, he hardly ever mentions the allies explicitly, let alone ethnic or local units. While the homogeneous nature of the Roman army suited his conception of "the solidity of the Roman state", he did not need to adapt the first to fit the latter. Polybius described the Roman army as he saw it. The picture is no different in many other battle narratives in the work of Livy, where we may suppose that he relied on such other Roman historians as Fabius Pictor or Coelius Antipater. We may observe that the Roman army as depicted by Sallust is as uniform as that described by Polybius. While the second-century Greek author could regard the role of the allies as inherent in Rome's harmonious unification of Italy and his Roman colleagues saw no reason for special emphasis, the position was much different for Roman historians of the first century BC, who felt the need for a more detailed and explicit role for the allies. The disturbed relationship with the allies, and the Social War in particular, played a role in this tendency, as witnessed by the deliberate effort to paint a favourable picture of the role played by soldiers from Fregellae and the Paeligni in the wars against Rome's enemies.

The campaigns that Livy (solely or largely) based on Valerius Antias are notoriously unreliable. Livy's late-annalistic battles in Italy during the years 213-207 BC include some dubious encounters between Marcellus and Hannibal, whereas Appian notes that Marcellus achieved little. The battles fought against the Ligurians, Gauls and Spaniards in the early second century BC are equally untrustworthy. Some of the battles 
that Livy took from Valerius Antias never occurred at all. Clearly, the passages in Livy's battle accounts on allied units offer a very insecure base for any theories on their role. The study of allied units should be based on Polybius and the more trustworthy parts of Livy. While the existence of ethnic or 'local' cohorts and cavalry units is beyond doubt, our conclusion leaves us with little secure evidence for their functioning in the period 218-168 BG. 